\title{
Incentive extension of pay-as-you-go pension system
}

\author{
Jan Mert1 \\ Department of Finance, University of Finance and Administration, \\ Prague, Czech Republic \\ jan.mertl@outlook.com \\ Jiř́i Mihola \\ Department of Economics, University of Finance and Administration, \\ Prague, Czech Republic \\ jiri.mihola@o2active.cr.

\section{Radim Valenčík} \\ Department of Economics, University of Finance and Administration, \\ Prague, Czech Republic \\ valencik@seznam.cr.
}

Abstract. Pension systems have been expecting projected deficits and governments have been under pressure to increase the statutory retirement age. Fully funded pension system pillars have significant limitations, the recent attempts to adapt social insurance systems have not provided plausible results and empirically have not had strong political support to be fully implemented. Therefore, we created an incentive-based pension system extension that enables a gradual transition to a merit-based pay-as-you-go system. We present a mathematical model based on virtual accumulation of resources that works with full working, relaxed and retired phases, based on the individual decision when to enter them. We present calculations based on the parameters that are valid in the Czech Republic, but the model is designed as a general one, therefore the model variables can be adjusted according to parameters in any country withpublic pension system. Then we discuss the implications and possibilities related to the model, also in the context of changes that we see in the labour market, behavioural patterns of the older generation and the socioeconomic development in the $21^{\text {st }}$ century.

Keywords: human capital, pension insurance, extension of pension insurance; voluntary pension pillar; active ageing.

JEL Classification: H55, H75, J24 


\section{INTRODUCTION}

The sustainability of pension systems (Bayar, 2013) has been discussed often since populations in developed countries started to age more intensively (OECD, 2017a). Additionally, general demographic behaviour and job market situation have been changing rapidly, this influences the macroeconomic situation, production structure and retirement strategies (Jaag, 2009). The changes that we shall focus on are financed from additional effects, that outcome from the incentive extension of pension system thanks to prolonging the time of active participation. Significant socio-economic dimension of those effects is the support of the intergenerational aspect of teamwork and the innovation potential of businesses. We shall also mention the role of education policy and schools in preparation of students for exploring teamwork possibilities and working in multigenerational teams (Bravo, Lucia-Palacios, \& Martin, 2016).

To implement this extension and achieve the effects of prolonging active participation, it is necessary to have a complex of reforms in the systems of social investment and social insurance. It means investment in education, healthcare and living standards in general, reliably and dependably organizing social insurance and human capital (Mincer, 1984) financing schemes (Kindermann, 2015). The more the pension system will have equivalency (earnings-related benefits) and closed (self-sufficient and balanced budget), the more effective will be its basic function of old-age security and strengthening the role of productive services that can prolong both horizon and zenith of citizens' productive employment (Valenčík, 2014).

Two main options for financing old-age pensions exist today: pay-as-you-go and fully funded one, but their characteristics and implementations matter the most (Baar, 2002). While theoretically (Feldstein, 1997) a transition to the fully-funded system is possible (Gyárfás\& Marquardt, 2001), it has significant problems that emerged in most of the countries that tried to do it (Kompa \& Witkowska, 2015), especially when introduced as compulsory of soft-compulsory pension pillar. Additional fully funded pillar's limitations include the dependency on the volatile performance of the capital markets, moral hazard lying in offering often subpar investment opportunities for clients striving for long-time pension security (and not speculation on stock exchange), inability to systemically adjust according the wage and price level (Zhang \& Ewald, 2010), tendency to put a burden of public finance (Drahokoupil \& Domonkos, 2013). They lead us to research policy options that needn't rely on capital markets and fully funded approach to run. This approach has been also seen in the literature as a result of experience with fully funded pillars (Zhang, 2007).

We have considered the reality in the Czech Republic (Czech Fiscal Council, 2018) and learned from the experience of the reform attempts that occurred during the last 20 years. We missed the incentive aspects in these reforms, at the same time, we saw changes in the national economy and structural economic policy that emphasize the needs for stable, self-sufficient social security systems that will be at least to a certain degree immune to external factors such as economic crises, market failures and also unsystematic interventions by politicians.

We also saw the reform attempts in other transition economies such as Poland, Slovakia and Baltic states and recognize that the attempts to adapt the pension system based on the philosophy of compulsory or soft-compulsory individual capital (fully-funded) pillars were debatable or demonstrated failing results (OECD, 2017a). That was another reason to design the incentive extension as a general model, so despite the calculations in this paper use the parameters from Czech national economy, it can be used in any pension system with solid first pillar financed from public budgets. It responds to the necessity to provide smoother and richer social security options, such as individual pension age choice and gradual decrease of working hours at higher age. In this approach, we see the main innovation brought by our research, since we recognize that the pension systems have struggled to implement adequate options 
for citizens to resolve the social situations that occur around the statutory pension age, also combined with the pressure to universally increase it.

\section{LITERATURE REVIEW, AIM AND METHODOLOGY}

The first methodological anchor to our approach forms the reasons for the incentive extension of the current social old-age pension insurance system.

The term "pension insurance" is commonly used without thinking about the risk that this system insures. The fact that sometimes we cannot give a satisfactory answer to this question leads us in some cases to leave the term "insurance" and replace it with the term "security". We shall now explain deeper how we see the problem in the context of used terminology.

Let us first look at how the term "pension insurance" is defined in the Czech act on pension insurance (Czechia, 1995). Section $\$ 1$ (1) states: "This Act regulates pension insurance (hereinafter referred to as "insurance") with respect to old age, invalidity and death of a breadwinner." When an insured event occurs (in the sense of old-age pension insurance) is regulated by Section 28: "An insured person is entitled to a retirement pension if he has acquired the necessary period of insurance and has reached the stipulated age, or possibly if he fulfils other conditions set forth in this Act." This definition is also taken over by the 2011 "small pension reform" regulation (Czechia, 2011).

Let us think about what these definitions say. According to them, the insured event is supposed to occur at a certain age. It is remarkably similar as if the law on compulsory accident insurance stated that the insured event would occur not in the event of a crash, but after going (let's say) 150,000 kilometres. As Goethe said, "whoever does not button up well, will not get dressed well". This definition of an insured event in the law leads to fundamental conceptual shortcomings both in the construction of the current pension system and in discussions about its reform.

In our approach, we assume that the insured event comprises loss of ability to provide enough means to live in dignity through the productive (gainful) activity as a result of ageing. This is an equivalent of invalidity insurance, where the cause of invalidity, however, does not comprise accident or illness, but the ageing process that affects an individual in a differentiated way (like injury or illness mentioned above). This means, among others, that the basic type of solidarity is the one between those, with respect to whom the insured event occurs (i.e., those who lose their full or partial ability to earn a living in job markets) and those who are also able to participate in job markets at a higher age.

In recent theoretical literature, Vostatek (2016) gives a clear overview of the main approaches to pension insurance. Based on the comparative analysis he presents the NDC system (notional defined contributions, contributory-defined, i.e., highly merit-based) as the most suitable and applicable. In defining the concept of incentive extension of the pension system and the creation of its model, which demonstrates the real nature of complex reforms of the social investment and social insurance system, we follow up on his work on pension systems' typology.

We also consider those works that in various aspects emphasize the importance and the possibility of selectively extending the horizons of the productive employment of human being beneficial. Vavrejnová et al. (2004) state that the issue of pension reform is not limited only to ageing and financial issues. According to them, it is a combination of diverse types of pension benefits and other types of savings together, which is particularly important, with extended economic activity. In this regard, Fiala and Langhamrová (2014) perform model calculations of income and expenditure developments of the pension system in the Czech Republic based on the latest demographic projection and taking into account the projected sustained increase of the retirement age, i.e., the period of productive employment of a person, and they logically conclude that the growth in share of persons with higher age will not result in such a 
large increase in the share of pensioners, i.e., increase in life expectancy will not automatically mean an increase in time of taking pension (Fiala, Langhamrová 2014, p. 233). Janíčko, Tsharakyan (2013) through a model show key importance of prolonging the period of productive employment and, based on this, formulate economic and political recommendations directed at different groups of people - especially women, people in higher productive age (55-64 years). According to them, the suitable measures should include retraining programmes, training programmes, active job search support, or efforts to reconcile family and work life, suitable incentive structure to extend periods of productive employment (Janíčko, Tsharakyan 2013, pp. 335-6). They conclude that using these options we can maintain the stability of the on-going pension system. Loužek (2014) views the problem as "security for retirement" where it considers three ways: savings, children, participation in the social pension insurance scheme (Loužek, 2014, p. 26). He concludes that older people need to be persuaded to continue in economic activity at a later age because they are worth it. His list of professions that are performed at an older age or possibly forever is interesting, (Loužek, 2014, pp. 94-95). It is worth mentioning one of the few works that deal with internal motivations to prolong the productive employment period and their effect from the point of view of lifelong costs of "impatience", giving preference to current consumption before investing in human capital (Cadena, Kays 2015). We also recognize the context of Czech public finance, fiscal situation and fiscal statistics, as it is contained in the work of Czech fiscal authorities (Czech fiscal council, 2018).

Based on the scientific discussions concerning the reform of the pension insurance system, that we have participated in during last three years, we have come up with the idea of full-closed and fully meritbased incentive extension of the current pay-as-you-go pension insurance system that can be easily and gradually implemented without significant problems and side effects and is based on voluntary participation. This can result in a gradual and smooth transformation of the entire pension insurance system. The extension is compatible with practically any volume of resources that the client can allocate into it. For our model, we calculate as a funding resource with the pension benefits from the first pension pillar that is available since achieving the statutory pension age, and the social insurance contributions that everybody pays from its work income (payroll amount). From empirical point of view (which is important when considering the applicability of research results and public choice behaviour), this path is more suitable than achieving a social consensus and ensuring enough political will to fundamentally reform the entire pay-as-you-go pension insurance system into the fully merit-based system of NDC type with a single basic pension benefit. In addition, our approach is compatible with NDC system in compulsory pension pillar if it is introduced in the future.

The second methodological anchor is to show conditionality of the so-called Industry 4.0 by a transition to an economy based on productive services, i.e., services that enable the acquisition, preservation, and employment of human capital. One of the main theorists of Industry 4.0 or more precisely the 4th industrial revolution is Mason (2015). He devotes extensive attention to Marx's "Grundrisse" manuscripts, noticing how Marx predicted the process of automation and computerization of the economy, but misses, like other contemporary theorists, what Marx considered to be the most important and what was understood and interpreted by Richta (1966) more than fifty years ago in a teamwork titled "Civilization at the Crossroads". Marx puts emphasis on expressing the form of real human abilities and what the development of human abilities means; person's ability to perform "general work", i.e. to mutually intermediate and to bring to one another the processes in the field of his or her activity. This specific human ability can develop in an unlimited way because it is directly linked to the development of scientific knowledge. That is why Marx emphasizes that saving of working time means increasing the "time for the full development of an individual, which in turn reverses the productive power of labour as the greatest productive force (Marx 1974, p. 343). It is about how to imagine this 
transformation of free time to the full development of an individual who is retrospectively the most important economic source.

Neglecting this idea then often leads to catastrophic reflections on the "uselessness" of most of the population. In fact, the complete opposite can be true. The so-called Industry 4.0 (as a major technological change) will release a large number of people from the industrial production process, but the demand will grow for people in the field of productive services for the acquisition, preservation and employment of human capital, and so will in the field of personal care services to save time in personal life (in order to meet every day needs and in the area of care-taking in order to prolong the time for creative professional activity). This absence is also reflected in the fact that those who speak about the problem of employing people released by so-called Industry 4.0 also point out that there are few people who would be able to perform the professional tasks required by Industry 4.0. This schism is clearly reflected in documents, in which the Czech government authorities devote attention to the so-called Industry 4.0 issue (MPO, 2015), (OECD, 2017a).

The fact is that the process of transforming the development of human capacities into a factor of economic growth and a change of the economic growth type implies an expansion of the productive services sector (education, healthcare, wellness etc.) and the transformation of this sector into the most important sector in the economy. We shall try to show that it implies a significant increase in the importance of teamwork and the formation of intergenerational and cross-generational teams aimed, among others, at mastering projects in the so-called Industry 4.0 field.

Based on these methodological anchors, the aim of this article is to introduce the incentive extension of the pay-as-you-go pension system and emphasize its role for active ageing (WHO, 2002). We have defined the theoretical background for an incentive-based approach to pensions, then we present mathematical model with a full description of equations and figures. Finally, we discuss the model's capabilities and importance in the current socio-economic environment.

\section{A MATHEMATICAL MODEL OF THE EXTENSION}

Firstly, we are going to define the basic concept of the fully closed and fully merit-based incentive extension of the current pay-as-you-go pension insurance system.

- The fully closed nature of the system means that all the resources that will come to this system will be distributed solely within this system (there need not be any capital revenues or government subsidies from outside, and no money will leave the system).

- The fully merit-based nature of the system means that pension benefits are based equivalently on what a person has paid into the system according to the rules we specify.

- We call the system an incentive pension system extension because it is only for those citizens who have reached the statutory retirement age.

- This is a voluntary extension of the primary pay-as-you-go pension insurance system. As such, this extension does not use capital or fully funded approach.

- Certain taxation of pension benefits is expected, from which a single basic benefit can be paid to all participants in the whole pension insurance system.

- It is also assumed that the system is voluntary (everyone can decide whether he will participate or not) and that the system is individually adjustable in the sense that it can be used by a participant of the system at any given time and by any percentage he may draw the relevant pension benefit, whereas the undrawn amount enters back into system as its virtual deposit.

Based on this notion, a mathematical model has been created (Mertl \& Valenčík, 2017). We can briefly describe the results of model construction and calculation as follows. 
- We assume a person with constant gross wage (e.g. $p=32000 \mathrm{CZK}$ - approximately the current (2018) average wage in the Czech Republic).

- We assume a social pension insurance contribution rate at $22 \%$ of the gross wage (e.g. $p s=7040$ CZK for wage 32000 CZK).

- We assume the expected length of life as an average of men and women (unisex approach) and the mortality tables as published by Czech Statistical Office in 2016 (CZSO, 2016).

- We assume that a person is entitled to a pension $v d=12000 \mathrm{CZK}$ from the pay-as-you-go social insurance since the social insurance statutory retirement age $(65$ years currently in Czech Republic). He pays both this whole amount and his social insurance contribution to the incentive extension and he does not receive any benefit during this payment phase.

- We assume the possibility of extension benefits' taxation like the standard income taxation (e.g. $15 \%)$.

- When retiring at the statutory retirement age (65 years) a person gets just old-age pension benefit from pay-as-you-go system $v d=12000 \mathrm{CZK}$.

Table 1

List of variables and their descriptions

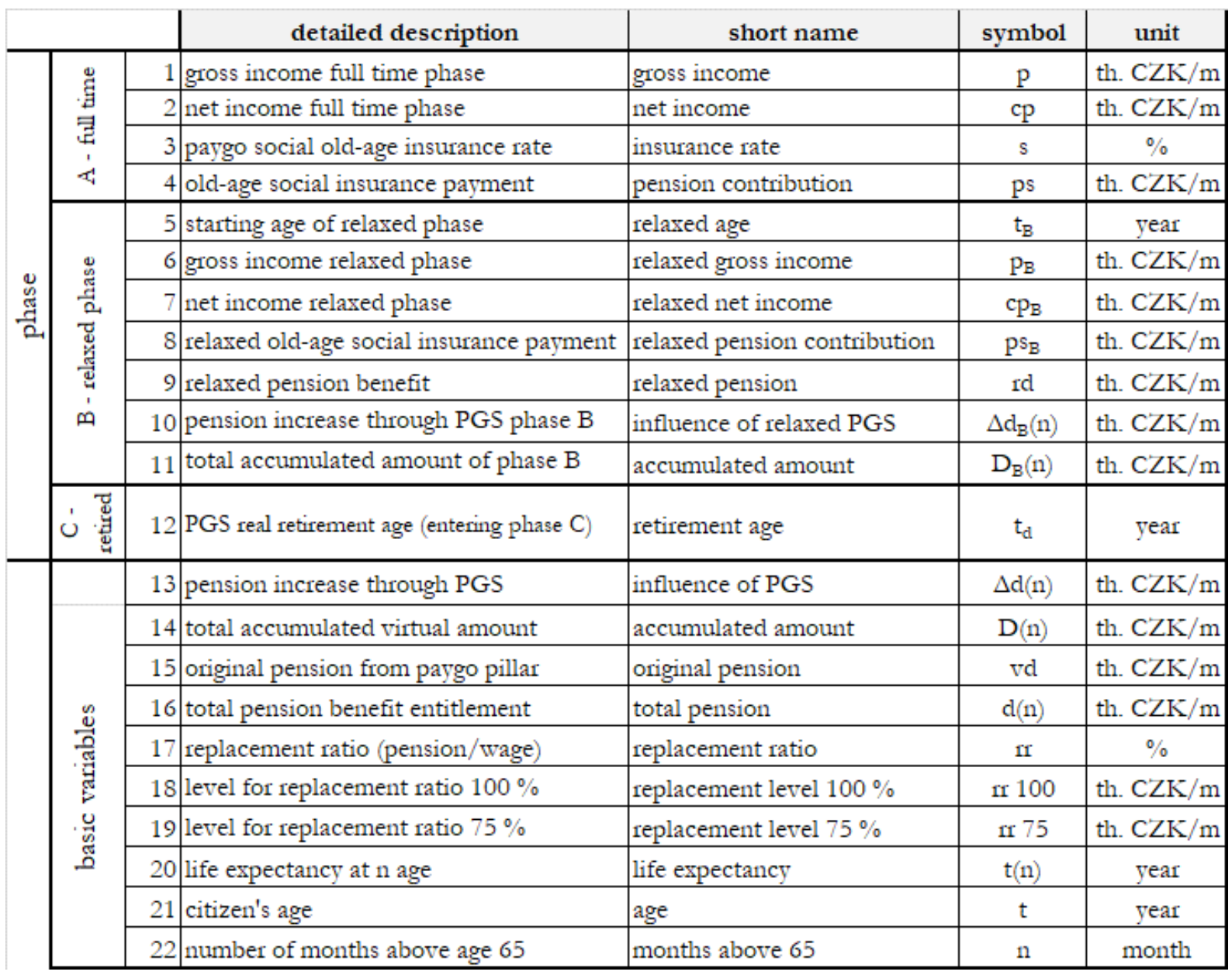

Source: authors 
These assumptions however just set the model's parameters, the model itself is compatible with any realistic settings of the input parameters and can adjust by them. Therefore, any country with solid first pension pillar can choose to implement this extension and adjust especially

- statutory pension age,

- contributions' level,

- income taxation

- projected average lengths of phases and wage level

so that they fit the situation in its social security system. All the model variables are concentrated in the Table 1, which contains both the short names and detailed descriptions, their symbols, and the corresponding units. In the following calculation algorithm, short names will be used.

When a person retires, in the year in which he claims his entitlement from the first pension pillar (regular social insurance), he has a certain gross income ${ }^{1}$ (wage, salary etc.), which we mark as $p$. This gross income corresponds to a certain pension's $v d$ entitlement that he can begin to receive when retired at the statutory retirement age (from the first pillar of social insurance). If he decides to work further and enters the incentive pension system (which we also call "postgraduate" pension system extension - PGS), he starts a phase which we call "full time working". This phase can be stopped at any time by decision of the client, and the total pension $\mathrm{d}(\mathrm{n})$ will be paid, which consists of the first retirement pension $v d$ and the increase in pension due to PGS $\Delta d(n)$.

$$
d(n)=v d+\Delta d(n)
$$

Where $\mathrm{n}$ expresses the number of months since reaching the age of retirement (statutory pension age). The variable $\mathrm{n}$ gains value $2 ; 1 ; 2, \ldots \mathrm{n}-1, \mathrm{n}$. If $\mathrm{n}=0$ there is the default calculation state. For simplicity, we will consider 65 years in our calculations and depictions, but the presented calculation is of a general nature. The number of months is to be watched because the calculations will be carried out every month, with the results being displayed for years to come.

The basic idea of calculating the monthly pension increase through PGS $\Delta d(n)$ is to calculate the cumulative amount $D(n)$ that holds all the amounts that a client does not draw but is entitled to ${ }^{3}$ and which has begun to pay into PGS. Therefore, the PGS client no longer pays the premiums into the first pillar (regular social pension insurance), but this amount (whole or part of it) is transferred to the incentive extension in the form of a $p s$ pension contribution, which is calculated as

$$
p s=s \cdot p
$$

where $\mathrm{s}$ is the social old-age pension insurance rate and $\mathrm{p}$ is the gross wage of the participant. The model works theoretically with any level of pension contribution or can even be zero (in this case only the $v d$ original pension will go into the incentive system extension), but in practice its maximum will be derived from gross income at the social insurance rate as shown above in equation (2), or it can be lower, as decided by the pension policy and the actual implementation of PGS. ${ }^{4}$

\footnotetext{
${ }^{1}$ For illustration purposes in this article we will use the income 32000 CZK (approximate equivalent of average gross wage in Czech national economy 2018).

${ }^{2} \boldsymbol{n}$ is an integer with the exclusion of negative numbers. Or, it is a set of natural numbers complemented by 0 .

3 There is no government subsidy, co-payments, or capital return in the cumulative amount (it needn't be, possible subsidies can be added if decided for the public choice, but the system works well even without them).

${ }^{4}$ We can also imagine that client will purely voluntarily decide how much he/she will pay into the system, in addition to decision when he retires or how he will decrease gradually his/her workload during ageing. This sounds good on paper, but we should then discuss how it would affect the behaviour of labour market, wages formation, labour contracts, and position of workers in different social groups. Because here we enter the territory of social insurance
} 
In the zero month (initial period), the cumulative amount is composed of two items, which are the pension contribution $p s$, and $v d$, i.e. the original pension from the pay-as-you-go social insurance, which he (still) does not need and does not draw.

$$
D(0)=p s+v d
$$

In the first month, the cumulative amount is composed of 4 items:

- the accumulated amount at the initial status of calculation $D(0)$,

- pension contribution $p s$,

- original pension $v d$,

- a monthly increase of pension through PGS at the initial status of calculation $\Delta d(0)$

$$
D(1)=D(0)+p s+v d+\Delta d(0)
$$

where the monthly increase of pension through PGS at the initial status of calculation $\Delta d(0)$ we get by dividing of the accumulated amount at the initial status of calculation by estimated life expectancy ${ }^{5}$ at the age $t(n)$. In our case, it is for the age of 65 equal to 18.12 years.

$$
\Delta d(0)=D(0) /(t(0) \cdot 12)
$$

For the n-th month is the calculation of the accumulated amount given by analogous equation to (4) equation.

$$
D(n)=D(n-1)+p s+v d+\Delta d(n-1)
$$

The increase of pension through PGS in $\mathrm{n}$-th month $\Delta d(n)$ is given by analogous equation to (5)equation - related to the decreasing average life expectancy as the participation in the extension continues (and the participant's real age increases).

$$
\Delta d(n)=D(n) /(t(n) .12)
$$

Schematically, the process of folding a cumulative amount is captured on the Figure 1. Given that the chart captures only the first 5 months, there is virtually no increase in PGS income in the $\mathrm{n}$-th month $\Delta d(n)$. In each added column (starting with the second one), the bottom horizontal hatched part of the column of the size of the previous column corresponds. The oblique hatching parts correspond to the original pension $v d$ and the pension contribution $p$ s.

The process of composing the cumulative amount up to 80 years of age is shown on Figure 2. Here is the increase in PGS income in the given year $\Delta d(n)$ well visible. Here again, the accumulation process is shown, because again the horizontally hatched part of the columns corresponds to the size of the entire earlier column. The oblique hatching parts correspond to the original pension $v d$ and the pension contribution $p s$. The graph is also supplemented by the decreasing duration of life expectancy $t(n)$ (dotted). In numbers, we can show the model data in the following Table 2.

contribution, their compulsory character, which is crucial, and any changes in this area, (e.g. allowing decreasing them voluntarily) must be thoroughly analysed from the point of view of all stakeholders.

5 We calculate life expectancy to remain simplified as the average of men and women. Life expectancy data for different ages is drawn from https://www.czso.cz/csu/czso/umrtnostni tabulky. The required monthly data is linearly approximated. 


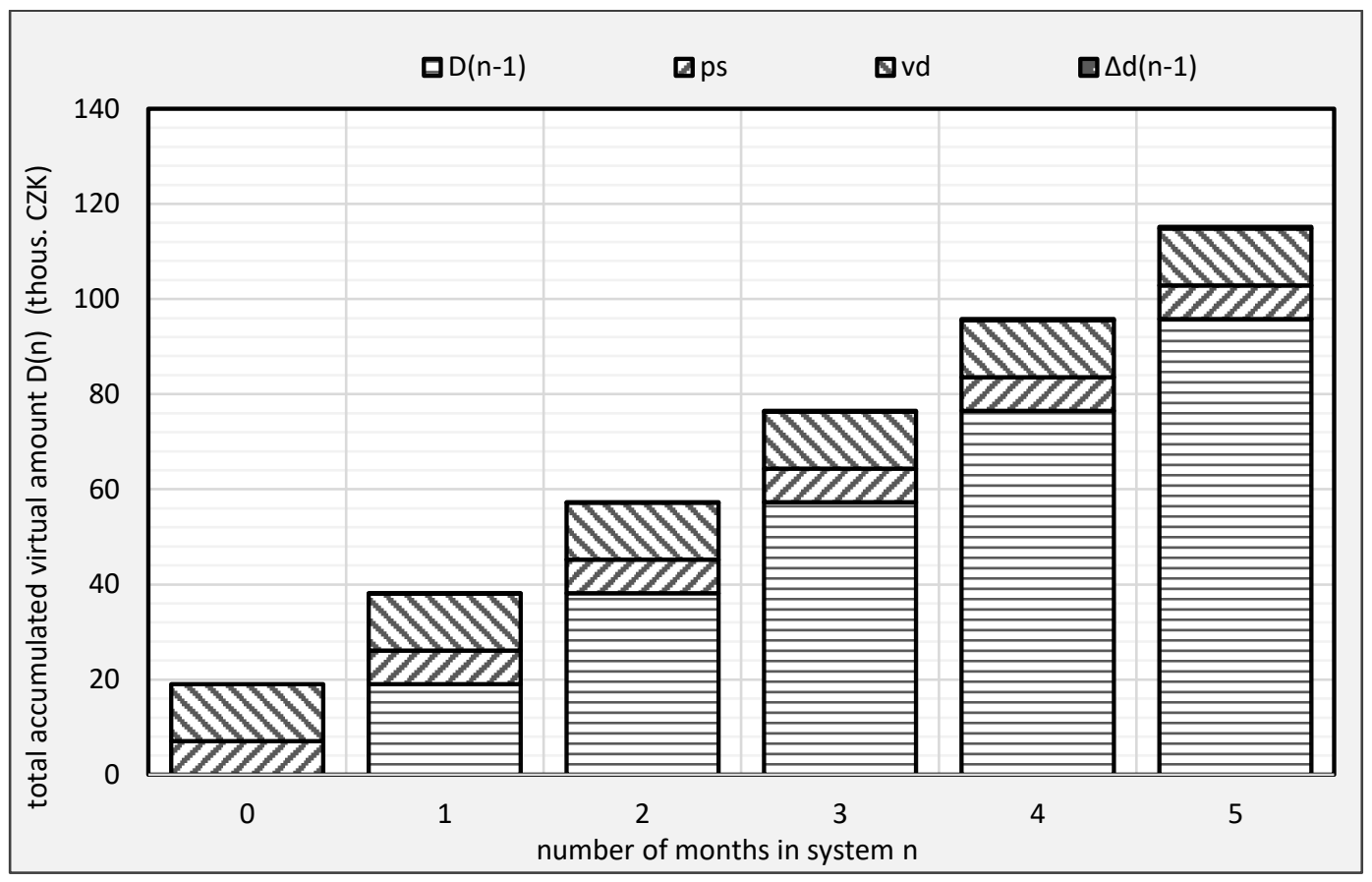

Figure 1. Illustration of monthly total virtual amount accumulation Source: own calculations

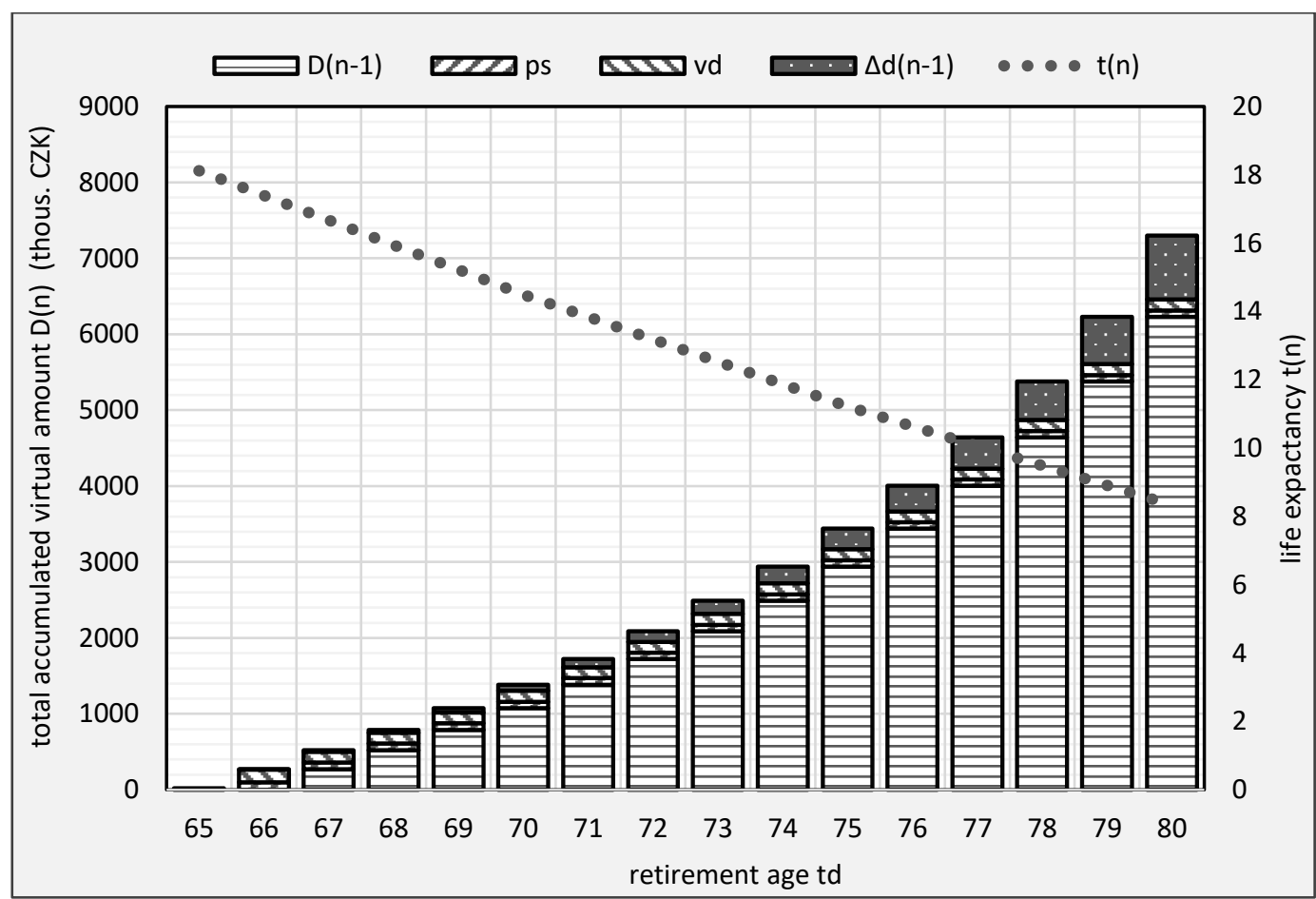

Figure 2. Illustration of yearly total virtual amount accumulation Source: own calculations 
Illustration of yearly total virtual amount accumulation

\begin{tabular}{|c|c|c|c|c|c|c|}
\hline $\begin{array}{c}\text { Age } \\
\boldsymbol{t}\end{array}$ & $\begin{array}{c}\text { Life exp. } \\
\boldsymbol{t}(\boldsymbol{n})\end{array}$ & $\begin{array}{c}\text { Amount paid } \\
\boldsymbol{D}(\boldsymbol{n})\end{array}$ & $\begin{array}{c}\text { Supp. pension } \\
\boldsymbol{\Delta} \boldsymbol{d}(\boldsymbol{n})\end{array}$ & $\begin{array}{c}\text { Original } \\
\text { pension } \boldsymbol{v} \boldsymbol{d}\end{array}$ & $\begin{array}{c}\text { Total } \\
\text { pension } \boldsymbol{d}(\boldsymbol{n})\end{array}$ & $\begin{array}{c}\text { Taxed } \\
\text { pension } \boldsymbol{d} \boldsymbol{d}(\boldsymbol{n})\end{array}$ \\
\hline 65 & 18.12 & 19.04 & 0.09 & 12 & 12.09 & 10.27 \\
\hline 66 & 17.40 & 254.64 & 1.22 & 12 & 13.22 & 11.24 \\
\hline 67 & 16.67 & 504.74 & 2.52 & 12 & 14.52 & 12.34 \\
\hline 68 & 15.95 & 771.58 & 4.03 & 12 & 16.03 & 13.63 \\
\hline 69 & 15.22 & 1057.84 & 5.79 & 12 & 17.79 & 15.12 \\
\hline 70 & 14.50 & 1366.84 & 7.86 & 12 & 19.86 & 16.88 \\
\hline 71 & 13.84 & 1702.38 & 10.25 & 12 & 22.25 & 18.91 \\
\hline 72 & 13.19 & 2068.91 & 13.08 & 12 & 25.08 & 21.31 \\
\hline 73 & 12.53 & 2472.22 & 16.44 & 12 & 28.44 & 24.18 \\
\hline 74 & 11.87 & 2919.51 & 20.49 & 12 & 32.49 & 27.62 \\
\hline 75 & 11.22 & 3419.93 & 25.41 & 12 & 37.41 & 31.79 \\
\hline 76 & 10.64 & 3984.01 & 31.20 & 12 & 43.20 & 36.72 \\
\hline 77 & 10.06 & 4624.45 & 38.29 & 12 & 50.29 & 42.75 \\
\hline 78 & 9.49 & 5358.84 & 47.07 & 12 & 59.07 & 50.21 \\
\hline 79 & 8.91 & 6210.24 & 58.09 & 12 & 70.09 & 59.57 \\
\hline 80 & 8.33 & 7209.41 & 72.11 & 12 & 84.11 & 71.49 \\
\hline
\end{tabular}

Source: own calculations

Considering that the total pension benefits at the age of 80 is already approaching the amount of $90000 \mathrm{CZK} /$ month and considering that the number of people who can or who intend to work full-time will be very few at this age, we consider it reasonable to end the curve (and the maximum presence in incentive pension system extension) at age of 80 .

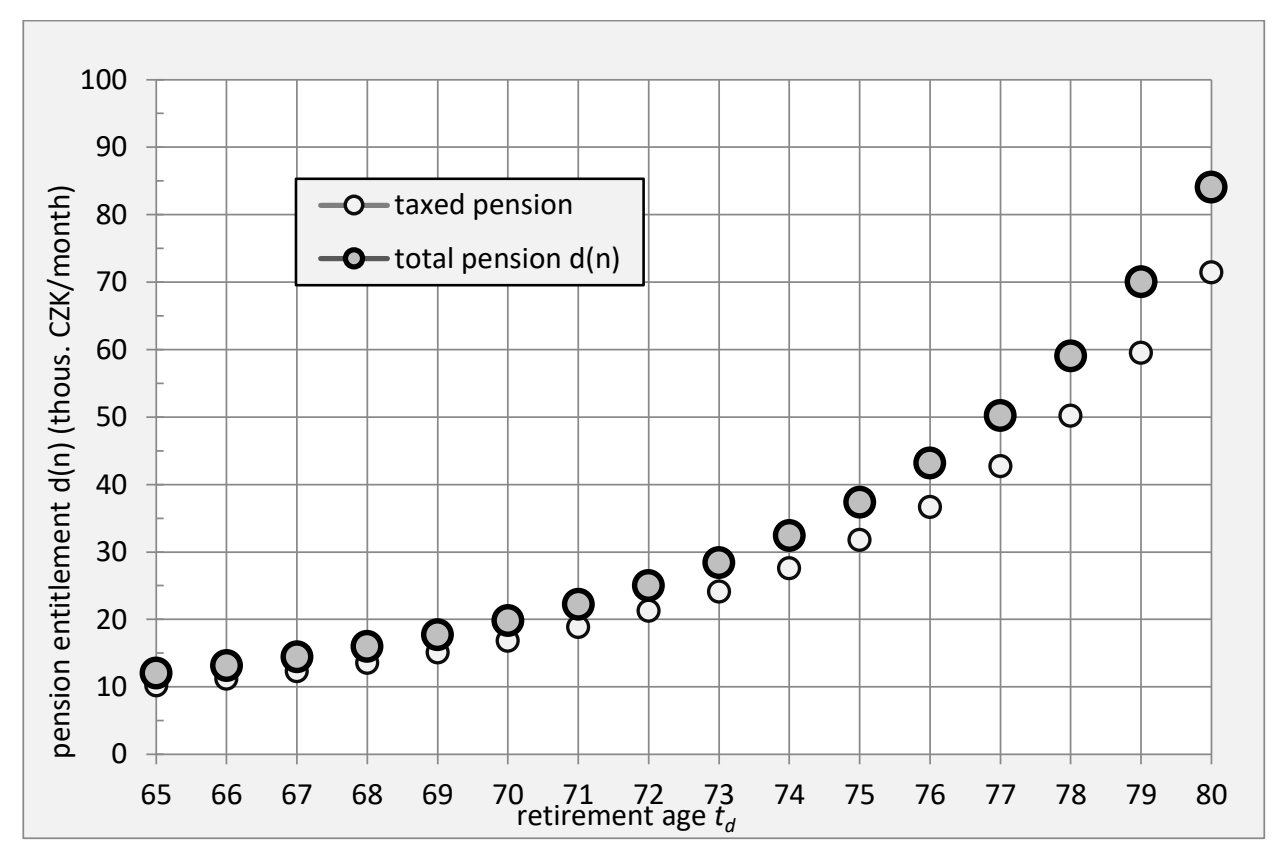

Figure 3. Incentive pension in PGS

Source: own calculations 
The curve of the resulting overall motivation income is plotted on the Figure 3. The smaller points in this chart show how the overall motivation income would look like at $15 \%$ tax rate.

The calculations so far have been devised to calculate the size of the incentive pension for those entering the scheme at the time of retirement age, for some time to continue working and after that to receive an incentive pension. However, it can be assumed that there will also be PGS clients who are in a situation that they want to continue working, but on a part-time basis, so they would be happy if the system would allow them only partial payments for some time. Such partial redemption will certainly result in a reduction in the final pension if the person concerned decides to stop the scheme. Such a stage of partial retirement will be called a relaxed phase (part-time working).

To illustrate the achievement of a stable replacement ration of $100 \%$ and $75 \%$ on the Figure 4 , a gross income of $32000 \mathrm{CZK} /$ month can be used (average gross wage 2018). This gross income corresponds to a net income of about $25000 \mathrm{CZK} / \mathrm{month}$, while $75 \%$ of this amount is 18000 $\mathrm{CZK} /$ month.

From Figure 4, it is easy to see that the total PGS income reaches a $100 \%$ replacement rate at around 71 years of age, i.e. after 6 years of participation in the incentive pension system, while $75 \%$ of the replacement rate is around 69 years, i.e. after 4 years of participation in the incentive pension system.

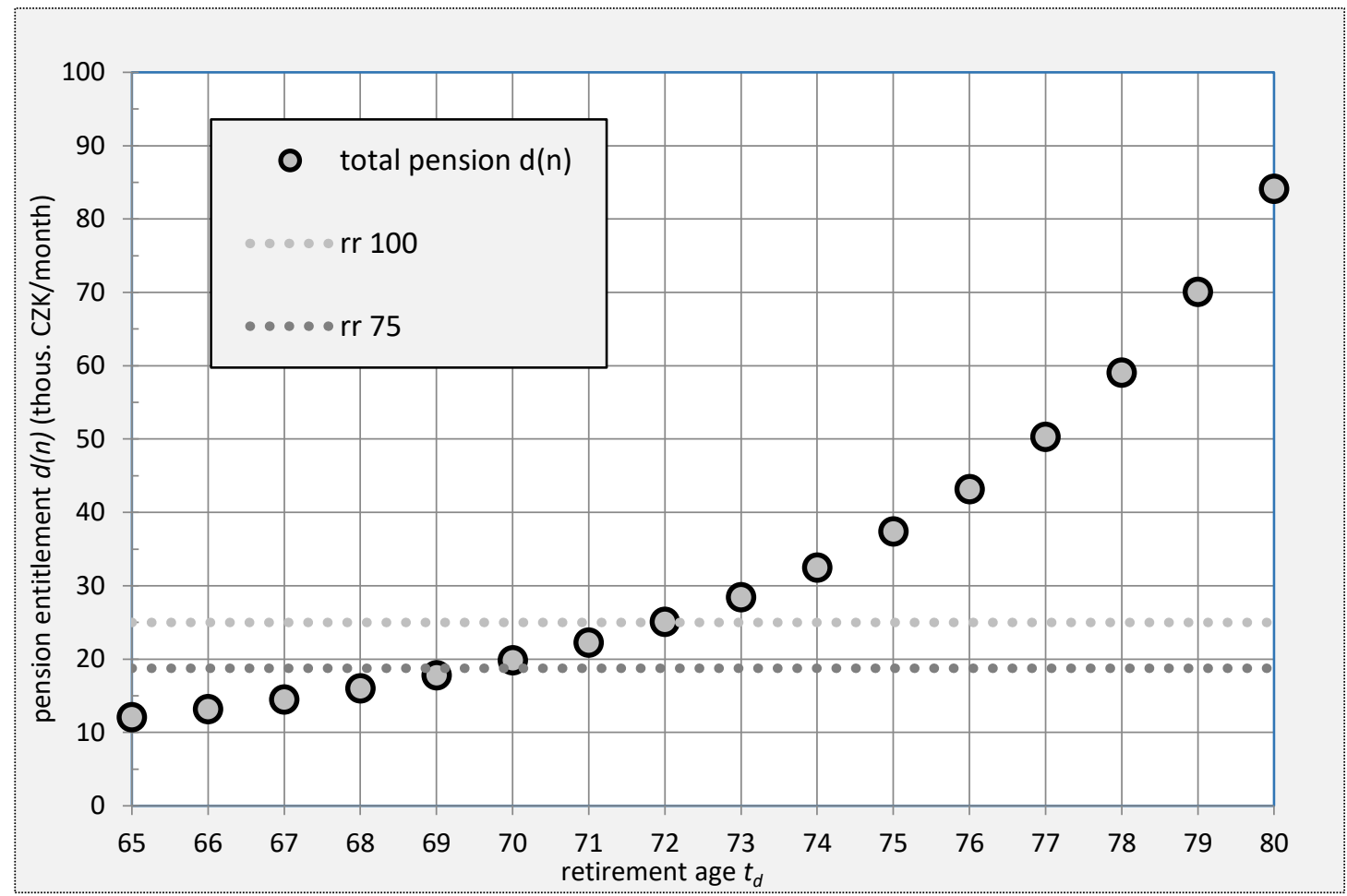

Figure 4. Reaching replacement ratios of $100 \%$ and $75 \%$

Source: own calculations

Algorithm of calculation for the relaxed phase:

A client in the incentive pension system may also decide to draw only partially from a certain age after entering the incentive scheme. The phase from the start to partial drawdown is called the full-time working phase. The time from the beginning of the partial drawdown to the moment of full drawdown is called the relaxed (part-time working) phase. The relaxed phase may also be zero, with the non-zero relaxed phase always reduces the overall incentive pension. The full-time working phase should not be 
zero, because then it is not enough to show motivational effects in a rapid increase in the overall incentive pension. Thus, the relaxed phase is more likely to be a solution to the situation of a noticeable decrease in income at a time when the person concerned can and still wants to work but to a limited extent. In this context, it is also proper to address the case where the decrease in income is compensated by the partial drawdown of the incentive system.

For the algorithm of relaxed phase, we also must set the age ${ }^{6}$ when the relaxed phase starts $t_{B}$ and desired relaxed pension $r d$ (in our example there is $r d=10$ ). If original gross wage was $p$, then gross wage at relaxed phase $p_{B}$ is lower $p>p_{B}$. In the relaxed phase we still have the social insurance rate $s$, therefore the lowered pension contribution $p_{s}$ is:

$$
p s_{B}=s \cdot p_{B}
$$

Three changes will be made to the cumulative amount during the relaxed period.

1. Into accumulated amount $D_{B}(n)$ we do not sum up the whole $v d$, but the difference between an original pension and relaxed pension that the client receives since entering relaxed phase, i.e. $v d-r d$. In our case it is $12-10=2$.

2. The client will pay a lowered amount for incentive pension $p s_{B}$.

3. From the accumulated amount will be deducted every month paid relaxed pension amount $r d$.

The expression for calculating the cumulative amount of the relaxed phase $\mathrm{B}$ is

$$
D_{B}(n)=D_{B}(n-1)+p s_{B}+(v d-r d)+\Delta d_{B}(n-1)
$$

Increase of pension through PGS in $\mathrm{n}$-th month $\Delta d(n)$ is given by expression analogous to (5).

$$
\Delta d_{B}(n)=D_{B}(n) /(t(n) \cdot 12)
$$

Calculation of accumulated amount must follow the calculations in the full working phase.

An example of calculating the increased incentive and relaxed pension benefits is on the Figure 5. Age, when client enters relaxed phase based on his own decision, is $t_{B}=70$ years. Relaxed pension is $r d=10$ and in the relaxed phase he pays pension contribution just $p s_{B}=3000 \mathrm{CZK}$.

From the Figure 5, it is clear how the incentive pension will change after the relaxed phase ends. Non-relaxed pension and increase are the same as on Figure 3 for comparison. In the following Table 3, we show the data, including the taxed pension, and greyed areas stand for the relaxed phase since the age of 70 .

${ }^{6}$ The age of entering the relaxed phase must therefore be higher than the age at which entitlement to the pension from first social insurance pillar arises (statutory retirement age) and must be less than 80 years, which is the upper limit of the incentive pension, so in our case $65<t_{B}<80$. 


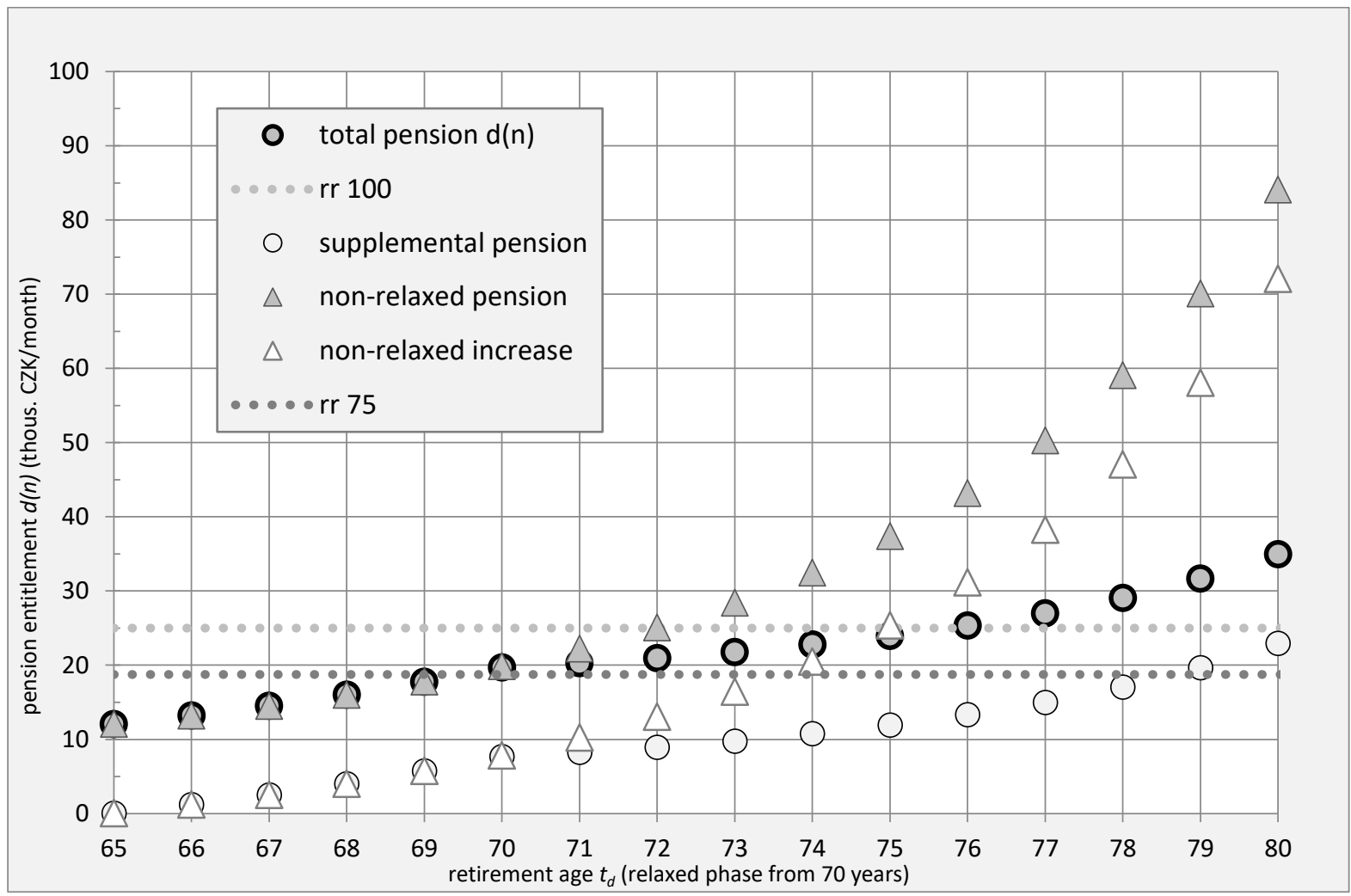

Figure 5. Incentive pension in full-time working and relaxed phase

Source: own calculations

Table 3

Data for incentive pension with relaxed phase since age of 70

\begin{tabular}{|c|c|c|c|c|c|c|}
\hline Age $t B=70$ & $\begin{array}{c}\text { Life exp. } \\
t(n)\end{array}$ & $\begin{array}{c}\text { Amount paid } \\
D_{B}(n)\end{array}$ & $\begin{array}{c}\text { Supp. pension } \\
\Delta d_{B}(n)\end{array}$ & $\begin{array}{c}\text { Original } \\
\text { pension } v d\end{array}$ & $\begin{array}{c}\text { Total pension } \\
d(n)\end{array}$ & $\begin{array}{c}\text { Taxed pension } \\
d d(n)\end{array}$ \\
\hline 65 & 18,12 & 19,04 & 0,09 & 12 & 12,09 & 10,27 \\
\hline 66 & 17,40 & 254,64 & 1,22 & 12 & 13,22 & 11,24 \\
\hline 67 & 16,67 & 504,74 & 2,52 & 12 & 14,52 & 12,34 \\
\hline 68 & 15,95 & 771,58 & 4,03 & 12 & 16,03 & 13,63 \\
\hline 69 & 15,22 & 1057,84 & 5,79 & 12 & 17,79 & 15,12 \\
\hline 70 & 14,50 & 1342,80 & 7,72 & 12 & 19,72 & 16,76 \\
\hline 71 & 13,84 & 1378,53 & 8,30 & 12 & 20,30 & 17,25 \\
\hline 72 & 13,19 & 1421,78 & 8,99 & 12 & 20,99 & 17,84 \\
\hline 73 & 12,53 & 1473,96 & 9,80 & 12 & 21,80 & 18,53 \\
\hline 74 & 11,87 & 1536,81 & 10,79 & 12 & 22,79 & 19,37 \\
\hline 75 & 11,22 & 1612,57 & 11,98 & 12 & 23,98 & 20,38 \\
\hline 76 & 10,64 & 1703,54 & 13,34 & 12 & 25,34 & 21,54 \\
\hline 77 & 10,06 & 1812,47 & 15,01 & 12 & 27,01 & 22,96 \\
\hline 78 & 9,49 & 1943,47 & 17,07 & 12 & 29,07 & 24,71 \\
\hline 79 & 8,91 & 2101,98 & 19,66 & 12 & 31,66 & 26,91 \\
\hline 80 & 8,33 & 2295,21 & 22,96 & 12 & 34,96 & 29,71 \\
\hline
\end{tabular}

Source: own calculations 


\section{THE MODEL'S IMPLICATIONS AND CAPABILITIES}

The primary objective of our model is not to show or suggest that if a person works as long as possible on the job market, his pension could reach very high amounts - that was just a demonstration of what the model is capable of. The aim was to show that with a suitably chosen lifelong career strategy one can gradually (e.g. after five years of full engagement in the incentive extension) loosen his workload, i.e., reduce his workload without lowering his disposable income and reducing the entitlement to payments from incentive system after completing full employment. It is even possible to achieve a concurrent loosening of workload and income increases in the form of incentive extension payments from the pension system, which can be used by persons of higher and senior age for both above-standard productive services, which allow the consumption of required services, which will allow substantial time savings for creative activity (Thanakwang \& Isaramalai, 2013).

The model and its testing show that the introduction of the incentive extension of the current pension insurance system is, among others, capable of:

- Ensuring uninterrupted sustainability of the pension insurance system with sufficiently high retirement benefits.

- Creating conditions for active ageing and quality fulfilment of life even in higher and senior age, both by creating funding resources and suitable motivations.

- Enabling gradual painless, risk-averse, and smooth reform of the entire current pension insurance system by shifting the threshold of statutory retirement age gradually lower than current 65 years according to legal retirement rules applicable for the first pension pillar. As we wrote in the methodology, this is currently not feasible in the Czech conditions, but the model can adapt to lower minimum statutory retirement age if adopted and adjust to the starting age of e.g. 62 or 60 years, or at least prevent the necessity to further increase the statutory retirement age, .

The main advantage of the model is that it shows the real possibility of creating an economic base for the expansion of productive services enabling the acquisition, preservation, and employment of human capital. Therefore, it is not only about how to ensure a decent standard of living and quality realization for people in older age, but primarily that a very strong and big demand for productive services and, at the same time, sources for their financing, which are created on a purely economic basis, is created by employing these people (to which the incentive extension motivates). This is not the only one, but significant and easily achievable, and concrete form of transforming the development of human abilities into the most dynamic factor of economic growth and the change in the character of this growth.

At this point, it is important to show how the benefits from the incentive extension can be utilized. In various life situations, the following usage may become essential:

1. Above-standard forms of health insurance and advanced schemes of health financing, which are oriented to prolonging the productive time and quality of life. From the pure point of view of financial flows, we consider this area to be the most important. As a practical alternative to private health insurance, which has strong limitations caused especially by the necessity of individual health risk evaluation (medical underwriting) and related information asymmetry, prepaid schemes for individually adjusted health packages can be considered. In the form of health savings accounts they also have disadvantages that become highly prominent if they are not supported by the good universal health system (they quickly fail in poorer, older or sicker population with no or weak universal coverage). Therefore, we designed the prepaid schemes as an extension of well-covering universal health care system and without special incentives to save money there, overcoming those disadvantages (Mertl, 2017).

2. Providing at older age social and support services that can enable the relevant productive person to spare time and energy in order to perform the relevant work activities. Nowadays, this is an 
underdeveloped sector of economy, which, of course, for many older experts' case, means a waste of human resources.

3. Educational activities in the context of lifelong learning. There is currently not a sufficiently sophisticated "upgrade" system that would be functional. It is an opportunity for universities to expand their sphere of activity at a time when income-raising opportunities in the form of student outreach are in fact already exhausted, and when due to a one-sided focus on mass tourism, some hidden demand was created for the further education of university graduates. the future can manifest in different forms.

4. Promoting and supporting professional activities to extend the (limited) productive time. In several concrete scenarios, this can be a key area of funds drawn from the incentive pension system's extension. It is a means of compensating income reductions due to the restriction of earning activities while keeping the ability to pay for the services mentioned in the preceding points. In other words, from a certain age (which may vary in individual cases, but the interval 70-75 years can be considered), it is appropriate to gradually reduce productive and gainful activities in such a way as to create conditions for preserving the ability of teamwork associated with the application of that knowledge and the experience he has gained during his life.

\section{INTERGENERATIONAL COMPLEMENTARITY, TEAMWORK, AND THE INNOVATION POTENTIAL OF SOCIETY}

One of the main objections to the proposed approach to pension reform in a direction that would motivate a person to prolong a period of voluntary productive employment includes the fact that extending the time of a person's productive application reduces opportunities for employing young people. If we rephrase this question into economic terminology, we can ask: Is there a substitutive or complementary relationship between the employment of people of different generations (i.e. older and younger)?

This question need not have a single answer. The relationship between the employment of older and younger persons, between the employment of members of different generations can be both substitutive (and then a displacement effect will apply) and complementary (and then an induction effect may apply in the sense that the more and the longer it is possible to preserve the employability of older people, the greater the opportunities to hire younger people). It depends on the type of productive, or more precisely gainful activities.

In general, it applies that in inertial development thinking there is a substitution relationship between the employment of older and younger people. This is mainly because job performance is more or less routine and individual. Young people are better suited to perform in it.

In case of development that is characterized by a high innovation intensity that is associated with the spread of innovation waves of higher intensity and higher density, i.e., in case of development that is based on human capital there is a complementary relationship prevailing between the employment of older and younger persons and induction effect is occurring here. This is mainly because the prerequisite of the preparation, suitable targeting and realization of the innovations comprises, by nature, performances not of a routine (i.e. creative) character; especially teamwork becomes necessary, namely, such teamwork that fully reflects the complementarity of performances not only of different skills but also of different generations. The importance of intergenerational transfer of professional experience grows and so does the importance of the innovative skills that one gets gradually during his professional career, which is based on long-time systematized and in practice verified knowledge.

In terms of requirements posed by the so-called Industry 4.0 (OECD, 2017b) we can say that the near future in performing economies will belong not only to teams as we know them today, but teams of 
three to four generations, i.e., intergenerational or rather cross-generational teams; teams that will be based on effective collaboration for up to four generations. Everyone who has been involved in realizing some significant innovation is aware of this.

Therefore, a comprehensive solution to the question related to the prolongation of term of productive professional employability of those persons who are capable of lifelong acquisition of knowledge in relation to gradually gained experience and who behave responsibly even in terms of preservation of their human capital, is of paramount importance for the economy, which is born from the current conditions.

The reader of this article can develop the clearest idea of what complementarity is in crossgenerational teams focused on implementation of innovations of higher order, among others, in connection with the question of what a precondition for social use is, i.e., the application of findings in practice, which are published in professional periodicals registered in recognized databases (Hinterlong, 2008). Finally, the final effect of published ideas is relatively rare, despite several intermediations, indirectly, based on circumstances. With the current way of functioning of the relationship between theory and practice, the theory presented in expert press and social practice, there is often even a substitute relationship between innovation and the applicability of knowledge. The higher the innovativeness, the more difficult is the immediate applicability. This is naturally due to the functioning of science in conditions of truly little developed team spirit, or more precisely the absence of innovation-based teams, both in the field of manufacturing and industry, as well as in services, including services provided by public institutions.

In an economy that is based on the application of significant innovation in the industry related to the use of options offered by Industry 4.0, as well as innovations in the sphere of institutional support for economy, the teamwork, ensuing from the generation of innovations, will form the basis of its performance. And under such conditions of non-inertial development, the demand for trans-generational complementary teams will grow significantly.

With a little exaggeration, it can be said that teamwork education in our education system ends at the kindergarten level and is very much disappearing from the university environment. Forms of interdisciplinary collaboration between students, also from different study years and branches, at universities are developed minimally. Especially the universities must adapt to the innovative approach.

The transition from a low-innovation economy of individual performances to an economy based on the systematic creation and dissemination of relevant innovation through interdisciplinary and transgenerational teams will occur while saving work (as indeed all sources), but the demand for productive activities of two kinds will also significantly increase:

Productive services activities aimed at acquiring, preserving, and employing human capital (which will become the base of the economy in an analogous way as the industry at the time of the industrial revolution became a dominant sector as opposed to agriculture).

Personal service activities (social care and assistance) that will save time in the out-of-work hours of those to whom these services will be provided, and more effective spending of leisure time (both in terms of relaxation and acquiring social contacts, etc.).

It concerns a complex transformation not only in the economic sphere but also in the social system. Their common denominator includes an emphasis that the fulfilment of the real wealth of human life in full use of the possibilities of development and the application of its abilities is simultaneously the principal factor determining the dynamics and quality of economic growth. Economy based on these foundations will be characterized by a high intensity and innovation breakthrough, leading to significant savings of all kinds of resources (raw materials, energy, time, labour), but will also generate demand for human abilities and their diversity, so that no one wanting to engage in economy of this type, will be 
unnecessary, will not be forced to live in a suffused enclave saturated from public sources. The changes in the pension system we are proposing can be one of the important stimuli that will lead to fundamental changes in the economy. This is exactly because they contribute to the creation of a real economic base, which will show the economic effect of services connected with the acquisition, preservation, and utilization of human capital (Valenčík, 2014).

\section{CONCLUSION}

Current Czech pay-as-you-go pension system is not prepared well for the changes that are required by the transition to an economy of productive services and prolonging active participation of citizens on the labour market. The full reform into NDC system has currently not been feasible within public choice framework, and fully funded pillars have their limitations, too. Therefore, we introduced incentive pension system's extension, which can relatively quickly increase the resources that a person can utilize at higher age to improve his living standard and quality of life. This extension is designed to fit basically any pension system with guaranteed first pension pillar based on public financing. The benefits from incentive extensions can be used for smoothing the consumption at an older age, financing the services that will help the older people to stay active as long as possible and desired while providing the flexibility required to avoid further statutory retirement age increases. Also, a gradual decrease in working hours is particularly important for older citizens.

This extension is targeted on a later period of life where it is most important, especially for some professions, to keep productive ability and utilize the lifelong experience. The resources for this extension can consist of pay-as-you-go pension benefits and social insurance contributions that the client is obliged to pay. The client can either have full engagement and then fully retire, or since some point, he can gradually decrease his engagement and start to receive the partial benefits during relaxed phase. The model can work with any realistic parameter settings and we are currently preparing spreadsheet templates that could be used for calculations of desired parameters according to equations and figures included in this article. The development of the model took significant research effort both with its construction and with its parameters' setting according to the possibilities and continuity with the current pension system that is running in the Czech Republic. Therefore, we believe it is worth to be presented in current form as a theoretical concept, but it has also promising potential into the future research and policy implementation because it can be used according to the needs of future reforms which can possibly change some of the input parameters.

Participation in incentive extension influences the job market and employment. Traditional inertia vision that older workers occupy jobs than could be overtaken by younger ones, and on the other hand that there are many jobs that cannot be done well by older workers has some merit. But it could be resolved (at least to some extent) by creation of cross-generational teams, specific jobs that will utilize mainly the experience of older workers, and transition to economy of productive services, which can create new working places based on demand for specific abilities and innovative concepts that require cooperation between generations rather than competition. This can help to overcome one of the issues of Industry 4.0 concept, where on one hand jobs could disappear and on the other hand, new qualifications and abilities are required.

\section{ACKNOWLEDGEMENT}

The result was supported by the students' project "Improvement pension system as an intensifying factor in the economy" with support for specific university research grant and also by the IGA project 
"Fiscal dimension and determinants of social policy effectiveness" at the University of Finance and Administration 2018.

\section{REFERENCES}

Barr, N. (2002). Reforming pensions: myths, truths, and policy choices. International social security review, 55(2), 3-36. doi: 10.1111/1468-246X.00122

Bayar, Y. (2013). Financial Sustainability of Pension Systems in the European Union. European Research Studies Journal,

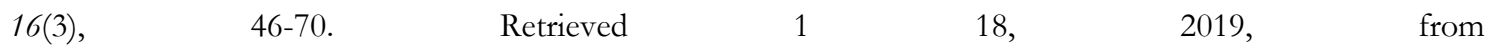
https://econpapers.repec.org/article/ersjournl/v_3axvi_3ay_3a2013_3ai_3a3_3ap_3a46-70.htm

Bravo, R., Lucia-Palacios, L., \& Martin, M. J. (2016). Processes and outcomes in student teamwork. An empirical study in a marketing subject. Studies in Higher Education, 41(2), 302-320. Retrieved 1 18, 2019, from http://tandfonline.com/doi/full/10.1080/03075079.2014.926319

Cadena, B., \& Kays N. (2015). Human Capital and the Lifetime Costs of Impatience. American Economic Journal: Economic Policy, 7(3), 126-153.

Czech Fiscal Council (2018). Report on the Long-Term Sustainability of Public Finances 2018. Prague: The Office of the Czech Fiscal Council. Retrieved 5 6, 2019 from https://unrr.cz/wp-content/uploads/2019/02/zpravaAJ.pdf

Czechia. (1995). Zákon č. 155/1995 Sb., o dìchodovém pojišténí. In: Sbírka zákonů. 30. 06. 1995.

Czechia. (2011). Zákon č. 220/2011 Sb., keterým se mèní qákon č. 155/1995 Sb., o duichodovém pojišténi a některé dalsí qákony. In: Sbírka zákonů. 21. 06. 2011.

CZSO (2016). Life expectancy tables for Czechia 2016. Available at: https://www.czso.cz/csu/czso/life_tables

Drahokoupil, J., \& Domonkos, S. (2013). Is the Egg Basket Worth Its Price? The Fiscal Implications of Pension Privatization in Eastern Europe. Retrieved 1 18, 2019, from https://ub-madoc.bib.uni-mannheim.de/36712

Feldstein, M. (1997). Transition to a Fully Funded Pension System: Five Economic Issues. National Bureau of Economic Research. Retrieved 1 18, 2019, from http://nber.org/papers/w6149

Fiala, T., \& Langhamrová, J. (2014). Modelování budoucího vývoje úhrnu pojistného a úhrnu vyplacených starobních důchodi̊ v ČR. Politická ekonomie. 62(2), pp. 232-248.

Gyárfás, G., \& Marquardt, M. (2001). Pareto improving transition from a pay-as-you-go to a fully funded pension system in a model of endogenous growth. Journal of Population Economics, 14(3), 445-453. Retrieved 1 18, 2019, from https://link.springer.com/article/10.1007/s001480000030

Hinterlong, J. E. (2008). Productive Engagement Among Older Americans: Prevalence, Patterns, and Implications for Public Policy. Journal of Aging \& Social Policy, 20(2), 141-164. Retrieved 1 20, 2019, from http://tandfonline.com/doi/abs/10.1080/08959420801977491

Jaag, C. (2009). Education, Demographics, and the Economy. Journal of Pension Economics \& Finance, 8(02), $189-223$. Retrieved 1 18, 2019, from https://alexandria.unisg.ch/22436

Janíčko, M., \& Tsharakyan, A. (2013). K udržitelnosti průběžného důchodového systému v kontextu stárnutí populace v České republice. Politická ekonomie. 61(3). pp. 321-327.

Kindermann, F. (2015). Earnings related pension schemes and human capital formation. Journal of Pension Economics \& Finance, 14(01), 19-54. Retrieved 1 18, 2019, from https://cambridge.org/core/journals/journal-ofpension-economics-and-finance/article/earnings-related-pension-schemes-and-human-capitalformation/ec834f8df29c8b124f67766a1dd77f3a

Kompa, K., \& Witkowska, D. (2015). Pension Funds in Poland: Efficiency Analysis for Years 1999-2013. Dynamic Econometric Models, 14, 105-124. Retrieved 1 18, 2019, from https://ideas.repec.org/a/cpn/umkdem/v14y2014p105-124.html

Loužek, M. (2014). Dưchodová reforma. Praha : Karolinum 2014.

Marx, K. (1974). Rukopisy „Grundrisse“II. Praha: Svoboda.

Mason, P. (2015). PostCapitalism. A Guide to Our Future. Allen Lane.

Mertl, J. (2017). Prepaid Schemes in Czech Health Care System. In Finardi, S. (ed). Proceedings of the 22nd Conference Theoretical and Practical Aspects of Public Finance 2017. Praha: VŠE. pp. 140-146. 
Mertl, J., \& Valenčík, R. (2017). Improving sustainability of human resources through pension system extension. In Janošová, L. (ed). Proceedings of the Conference of Business Economics, Management and Marketing ISCOBEMM 2017. Zaječí MU Brno, 2017. pp. 180-191. Available at: https://iscobemm.com/wpcontent/uploads/ISCOBEMM-2017-Conference-Proceedings.pdf .

Mincer, J. (1984). Human capital and economic growth. Economics of Education Review, 3(3), 195-205. Retrieved 1 18, 2019, from http://nber.org/papers/w0803

MPO. (2015). Národní iniciativa Primysl 4.0. Available at: http://www.businessinfo.cz/cs/clanky/narodni-iniciativaprumysl-40-71386.html .

OECD. (2017a). Pensions at a Glance 2017: OECD and G20 Indicators. Paris: OECD Publishing.

OECD. (2017b). The Next Production Revolution: Implications for Governments and Business. Paris: OECD Publishing.

Richta, R. et al. (1966). Civilizace na rozcestí. Praha: Svoboda.

Šimková, M., Sixta, J., \& Langhamrová, J. (2016). Penzijní závazky stárnoucí populace České republiky [Pension Liabilities to Ageing Population of the Czech Republic]. Politická ekonomie, 2016(5), 591-607.

Thanakwang, K., \& Isaramalai, S.-a. (2013). Productive engagement in older adults: A concept analysis. Nursing \& Health Sciences, 15(1), 124-130. Retrieved 1 20, 2019, from http://onlinelibrary.wiley.com/doi/10.1111/nhs.12015/full

Valenčík, R. et al. (2014). Perspektivy a financování odvétví produktivnich slǔ̌eb. Praha: VŠFS EUPRESS.

Vavrejnová, M., Belabed, E., \& Wörister, K. (2004). Pension reform in the Czech Republic: present situation and future prospects (a comparison with Austria). Prague economic papers, 13(3), 237-259.

Vostatek, J. (2016). Penzijni teorie a politika. $1^{\text {st }}$ ed. Praha: C. H. Beck.

WHO. (2002). Active Ageing: A Policy Framework. Geneve: WHO.

Zhang, A., \& Ewald, C.-O. (2010). Optimal Investment for a Pension Fund Under Inflation Risk. Mathematical Methods of Operations Research, 71(2), 353-369. Retrieved 1 18, 2019, from http:// eprints.gla.ac.uk/55026

Zhang, W. (2007). Further Reform of China's Pension System: A Realistic Alternative Option to Fully Funded Individual Accounts. Asian Economic Papers, 6(2), 112-135. Retrieved 1 18, 2019, from https://ideas.repec.org/a/tpr/asiaec/v6y2007i2p112-135.html 